\title{
The Effect of Coconut Water in Reducing Fatigue among Workers in North Sumatera
}

\author{
Bona Rina Ria Rajagukguk1), Nurmaini²), Etti Sudaryati3) \\ 1)Department of Occupational Health and Safety, Faculty of Public Health, \\ Universitas Sumatera Utara \\ 2)Department of Environmental Health, Faculty of Public Health, \\ Universitas Sumatera Utara \\ 3)Department of Public Health Nutrition, Faculty of Public Health, \\ Universitas Sumatera Utara
}

\begin{abstract}
Background: Fatigue can reduce working performance, worker motivation, and work productivity. Fatigue due to exposure to heat pressure which causes excessive sweating must be overcome through the provision of fluids that are right for workers. Coconut water contains electrolytes, so it is very good to replace lost body fluids during activities throughout the day. The purpose of this study is to analyze differences in work fatigue with interventions giving 4 liters of drinking water and giving 1 liter of young coconut water (Cocos nucifera L.) accompanied by giving 3 liters of drinking water.

Subjects and Method: This study is a quasi-experimental design with a research design of one group pre and post test design. The study population was the production of cassava chips factory workers with a total sample of 20 people. The sampling technique is purposive sampling. The dependent variable is work fatigue while the independent variable is giving 4 liters of drinking water and giving 1 liter of young coconut water (Cocosnucifera L) accompanied by giving 3 liters of drinking water. The type of data collected is primary data in the form of work fatigue (in milliseconds) measured using the Reaction Timer. Bivariate analysis was conducted using the paired T test.

Results: Fatigue after giving 1 liter of young coconut water and 3 liters of drinking water was lower $($ mean $=118.00 ; \mathrm{p}=0.001)$ than the group given 4 liters of drinking water $($ mean $164.94 ; \mathrm{p}=$ 0.001).

Conclusion: Work fatigue in the group given 1 liter of young coconut water and 3 liters of drinking water was lower than the group given 4 liters of drinking water.
\end{abstract}

Keywords: fatigue, young coconut water, drinking water, heat pressure

\section{Correspondence:}

Bona Rina Ria Rajagukguk. Department of Occupational Health and Safety, Faculty of Public Health, Universitas Sumatera Utara, Medan, North Sumatera. Email: bonarinaria@gmail.com. Mobile: 081370185933 .

\section{BACKGROUND}

Fatigue is one of the unsafe conditions and can be a serious problem in the working environment. Fatigue can reduce work performance, worker motivation, and work productivity (Maurits, 2017). The work environment is not only safe and sound but must also encourage personal and professional development, job satisfaction and per- sonal fulfillment. All of that will contribute to improving the quality and productivity of work (Gardiner and Harrington, 2005). Workplaces that have chemical hazards, physical hazards, biological hazards and psychosocial hazards have the potential to cause physical and psychological impacts on workers (Lerman et al., 2012). 
One potential danger of environmental factors is heat pressure (Plog \& Quinlan, 2010). Heat pressure can occur in hot environments such as production rooms. The production process involves high temperatures, sources of heat pressure, high humidity, direct physical contact with hot objects, or heavy physical activity that have high potential to cause heat-related diseases (United States Department of Labor, 2017). Heat pressure in workplaces that do not meet the requirements can cause work discomfort, heavy additional burdens and cause health problems for workers (Sumakmur, 2014).

During activity in a hot environment, the body will automatically give a reaction to maintain a constant range of environmental heat. The trick is to balance the heat received from outside the body with loss of heat from the body (Tarwaka et al., 2004). Excessive heat conditions will result in fatigue and drowsiness, reduce stability and increase the number of workplace errors (Nurmianto, 2004). Nurullita and Joko (2007) reported that the results that there is an influence of heat pressure on work fatigue on workers in the arc furnace and rolling mill.

Someone is said to be exposed to fatigue due to heat pressure when exposed to high temperatures and heat symptoms and symptoms such as increased pulse rate, excessive sweating, fatigue, confusion, nausea and drastically elevated body temperature (US Department of Health and Human Services, 2010). If the workforce begins to feel tired but still forces himself to work, the fatigue will increase. Such fatigue conditions will disrupt the smooth running of work and have an impact on productivity (Tarwaka, 2013) and cause accidents and occupational diseases (Salami et al., 2015).

Fatigue due to exposure to heat pressure will cause excessive sweating. This condition must be overcome through the provision of fluids that are appropriate for workers (Miller and Bates, 2007). Proper replacement of body fluids and electrolytes will reduce the more severe effects of dehydration (Jamaludin et al. 2012). The application of strategies by maintaining adequate hydration of workers is the most important intervention in the management of a hot work environment (Miller and Bates, 2010).

People who work in sufficiently hot conditions for 10 hours on average lose between 4.8-6 grams of sodium $(\mathrm{Na})$ equivalent to 12-15 grams of salt $(\mathrm{NaCl})$ depending on one's acclimatization. This important electrolyte must be replaced to avoid imbalance of fluids in the body (Bates \& Miller, 2008). Normal hydration can be achieved with various kinds of water intake depending on heat pressure exposure (Sawka, 2005). Workers must equip the body with fluids and electrolytes while working in hot environments. Drinking water must be available in the workplace in an unlimited amount (Koradecka, 2010).

As a tropical country, coconut plants are not difficult to find in Indonesia. This plant is widespread throughout the Indonesian archipelago. Utilization of the right coconut products as Indonesia's natural wealth can provide great benefits for the community (Barlina, 2004).

Coconut water contains high electrolytes so it includes natural isotonic drinks. The mineral content is very good for replacing lost body fluids during activities throughout the day. Naturally, young coconut water has a perfect mineral and sugar composition so that it has the right electrolyte balance, just like human body fluids (Bogadenta, 2013).

According to the United States Department of Agriculture (USDA, 2016), in 100 gr coconut water has an energy content 
of $19 \mathrm{kcal}$, protein $0.72 \mathrm{~g}$, carbohydrates $3.71 \mathrm{~g}$, sugar $2.61 \mathrm{~g}$ and the content of electrolytes include potassium (250 mg), phosphorus (20 mg), iron (0.29 mg), zinc (0.1 $\mathrm{mg}$ ) and water (94.99 g). Coconut water also has chloride content $(1,830 \mathrm{mg} / \mathrm{l})$, magnesium (262 $\mathrm{mg} / \mathrm{l})$, manganese (49 ppm), sulfur (35.4 ppm) (Barlina, 2004). Vita (2016) also said that in $30 \mathrm{ml}$ of coconut water contained $61 \mathrm{mg}$ of potassium, $5.45 \mathrm{mg}$ of sodium and $1.3 \mathrm{mg}$ of sugar.

Coconut water has five important electrolytes needed by the human body. Potassium has a function in regulating heart rate and muscle function. Sodium is the most important positive ion in fluids outside the cells of the human body (loss of sodium through sweat and urine). Magnesium is to maintain cell electrical potential, proper muscle function and prevent excess calcium. Phosphorus has an important role in health bones in transferring energy throughout the body, helping muscles contract and regulate nerve function (partnering with calcium). Calcium has an important function for bone health (Reddy \& Lakshmi, 2014).

\section{SUBJECTS AND METHOD}

This was a quasi-experimental study with a pre and post test design. The study was conducted to analyze differences in work fatigue with intervention in giving 4 liters of drinking water and giving 1 liter of young coconut water (Cocos nucifera L)and also by giving 3 liters of drinking water.

The study population was workers in the production of cassava chips in the Taduk Subdistrict, STM Hilir Village. The number of samples is 20 people. The sampling technique is purposive sampling. Sampling techniques that consider certain criteria in the population to be sampled (Sugiyono, 2014).
The dependent variable in this study is work fatigue while the independent variable is giving 4 liters of drinking water and giving 1 liter of young coconut water (Cocos nucifera $L$ ) and also 3 liters of drinking water. The type of data collected is primary data in the form of work fatigue (in milliseconds) measured by using the Reaction Timer. The work exhaustion obtained was the value of work fatigue before and after intervention for 3 days of treatment.

The intervention was carried out for 6 days. On the first day (morning), initial work fatigue measurements were carried out before the intervention giving 4 liters of drinking water. After giving 4 liters of drinking water for 3 days, work fatigue measurements were carried out again (third day in the afternoon). Then on the 4 th day the initial work fatigue (morning) was measured before the intervention giving 1 liter of young coconut water and 3 liters of drinking water. After giving the intervention for 3 days the work fatigue measurements were carried out (sixth day in the afternoon). Data were analyzed by paired ttest to examine mean difference of fatigue before and after intervention.

\begin{tabular}{l}
\hline RESULTS \\
The pretest and posttest measurements \\
were carried out to see the difference in the \\
level of work fatigue before and after the \\
intervention for 6 days. During the study, \\
respondents were not allowed to consume \\
other fluids such as electrolyte packaging or \\
other supplemental drinks to avoid re- \\
search bias. \\
1. Heat pressure in production room \\
and sample characteristics \\
The ISBB measurement results showed that \\
the average heat pressure in the production \\
section was $31.30^{\circ} \mathrm{C}$. The results of the \\
study also showed that the average age of
\end{tabular}


20 respondents was 34.30 years old and the average length of service was 6.28 years.

Table 1. Level of heat pressure and sample characteristics

\begin{tabular}{lcc}
\hline Variables & Mean \pm SD & Min-Max \\
\hline Heat pressure & $31.30 \pm 1.13$ & $29.90-33.00$ \\
Age & $34.30 \pm 9.47$ & $23.00-53.00$ \\
Working period & $6.28 \pm 3.78$ & $1.00-14.00$ \\
\hline
\end{tabular}

The condition of heat pressure $\left(31.30^{\circ}\right.$ C) exceeded the allowable NAV according to Permenaker Number 5 of 2018 for moderate workloads with working time arrangements every hour (75\%-100\%) which was $28^{\circ} \mathrm{C}$ (Ministry of Manpower of the Republic of Indonesia, 2018).

\section{Level of Work fatigue}

The measurement of work fatigue for 20 respondents was carried out in first intervention and the second intervention. The first intervention was by giving 4 liters of drinking water. The second intervention was by giving 1 liter of young coconut water and 3 liters of drinking water.

Table 2.Work Fatigue Level Before and After Intervention

\begin{tabular}{ccccccccc}
\hline & \multicolumn{3}{c}{ Work Fatigue Level of 1 Intervention } & \multicolumn{3}{c}{ Work Fatigue Level of 2 Intervention } \\
\cline { 2 - 9 } & Pretest & Posttest & $\Delta$ pre-post & \% & Pretest & Posttest & $\Delta$ pre-post & \% \\
\hline Mean & 261.02 & 164.94 & 96.08 & 36.88 & 267.41 & 118.00 & 149.41 & 55.02 \\
\hline
\end{tabular}

Based on the table above, it can be seen that there was a decrease in work fatigue by $36.88 \%$ with a mean difference of 96.08 milliseconds in the first intervention. In the second intervention, the decrease in work fatigue was $55.02 \%$ with a mean difference in decline of 149.41 milliseconds.

\section{The Results of Different Tests for Work Fatigue}

Table 3. Results of analysis of t-paired tests work fatigue before and after intervention of the administration of 4 liters of drinking water

\begin{tabular}{lccccc}
\hline Work Fatigue & n & Mean \pm SD & Mean Difference & 95\% CI & p \\
\hline Before Intervension & 20 & $261.02 \pm 25.58$ & $96.08 \pm 25.54$ & $84.13-108.03$ & 0.001 \\
After Intervension & 20 & $164.94 \pm 30.45$ & & & \\
\hline
\end{tabular}

Table 4. Results of analysis of t-paired tests work fatigue before and after intervention of 1 liter of young coconut water and 3 liters of drinking water

\begin{tabular}{lccccc}
\hline Work Fatigue & $\mathbf{n}$ & Mean \pm SD & Mean Difference & $\mathbf{9 5 \%}$ CI & p \\
\hline Before Intervension & 20 & $267.41 \pm 41.67$ & $149.41 \pm 44.73$ & $128.48-170.34$ & 0.001 \\
After Intervension & 20 & $118.00 \pm 20.74$ & & & \\
\hline
\end{tabular}

Table 3 and Table 4 showed that there were significant differences in mean work fatigue before and after giving 4 liters of drinking water and before and after administration of 1 liter of young coconut water with 3 liters of drinking water $(\mathrm{p}=0.001)$.

\section{DISCUSSION}

High combustion temperatures and long exposure to heat during the production of chips can have an impact on the high temperature of the surrounding work environment. This hot work location was also supported by the condition of air vents, the amount which was not in accordance with the floor area of the production room so that air circulation and heat pressure did not occur properly and can give an impact to the health conditions of workers in the 
production section. One of the consequences was work fatigue due to heat stress.

When workers got a heat exposure of $31.30{ }^{\circ} \mathrm{C}$ (exceeding the permissible NAV) and were supported by hot weather conditions, air vents that did not match the floor area of the production room would result in excessive sweating. The reaction was a form of the body's reaction to cool down and reduce the effects of heat stress. When excessive sweating was not balanced with adequate fluid consumption it would cause dehydration and have an impact on the health of workers such as work fatigue due to heat stress (Jacklitsch et al., 2016).

It was not uncommon for workers to lose fluid for $2-3 \%$ of their body weight. Therefore, it was important to encourage workers who were exposed to heat to consume sufficient fluid intake so that there was no dehydration or fatigue. Activities with 1-2 hours of heat exposure only required water. However, when prolonged sweating for several hours in a hot environment, it was recommended to drink electrolyte fluids such as young coconut water to replace lost electrolytes when sweating (do not exceed $8 \%$ of volume) (Jacklitsch et al., 2016).

Paired t test results showed a significant difference in mean work fatigue $(\mathrm{p}=$ o.001) during the three days of intervention of 4 liters of drinking water and three days of intervention of 1 liter of young coconut water and also 3 liters of drinking water. These results proved that the two interventions can significantly reduce work fatigue (Table 3 and Table 4). A decrease of 55.02\% of work fatigue on the provision of 1 liter of coconut water and 3 liters of drinking water occurred significantly when compared to the provision of 4 liters of drinking water which was only $36.88 \%$. Therefore, it can be concluded that giving 1 liter of young coconut water and 3 liters of drinking water was more effective in reducing work fatigue compared to the intervention of 4 liters of drinking water.

Coconut water, especially young coconut water contained glucose and electrolytes such as sodium (sodium), potassium (potassium), chloride, and magnesium which were useful as oral rehydration fluids. In $100 \mathrm{ml}$ of coconut water, there were $9.17 \mathrm{mg}$ of sodium, $173.50 \mathrm{mg}$ of potassium, $15.01 \mathrm{mg}$ of magnesium, 47.98 $\mathrm{mg}$ of calcium and $3.92 \mathrm{mg}$ of phosphorus (Medeiros and Medeiros, 2012). Vita (2016) stated that in $30 \mathrm{ml}$ of coconut water, it contained $61 \mathrm{mg}$ of potassium (potassium), $5.45 \mathrm{mg}$ of sodium and $1.3 \mathrm{mg}$ of sugar. Coconut water was also a source of manganese, and contained $60 \%$ minerals as the recommended daily ideal amount.

Coconut water was not ordinary fruit juice. The acidity of low coconut water and combined with a balanced sugar content and isotonic mineral composition made it a potential rehydration liquid and sports drink (Prades et al., 2012). The results of research on fishermen (Buwana et al., 2016) indicated that having 1 liter of young coconut water can significantly reduce work fatigue $(\mathrm{p}=0.001)$.

Based on the results of this study, it was recommended that the provision of 4 liters of drinking water can be used as a corrective action on work fatigue due to exposure to heat pressure that exceeded the $\mathrm{NAB}$ because it can reduce work fatigue by $36.88 \%$.

Giving 1 liter of young coconut water and 3 liters of drinking water can be a recommendation for workers who were exposed to heat pressure which exceeding the permitted NAV (Ministry of Manpower of the Republic of Indonesia, 2018) to reduce work fatigue due to heat stress in the work environment. Natural isotonic which contained carbohydrates, antioxi- 
dants, enzymes and various essential vitamins and minerals for the body that have been recognized as oral fluids to restore dehydration by replacing lost electrolytes due to physical exercise, exposure to heat stress or disease(Reddy \& Lakshmi, 2014).

Workers who were exposed to heat should consume fluids of at least 4 liters/8 hours of work with the details of consuming by $250 \mathrm{ml}$ every 20-30 minutes as recommended by the National Institute for Occupational Safety \& Health (Jacklitsch et al., 2016).

Employers must provide enough drinking water that was easy to reach for workers who worked in hot working environments. Employers can also did a job rotation to reduce the impact of heat pressure exposure.

Improvement of air circulation with the addition of air vents, use of exhaust fans or the use of turbine ventilators so that air circulation can rotate properly and heat flow can be removed from the production room and minimize the impact of exposure to high heat pressure on workers (OSHA, 2005).

\section{REFERENCES \\ Barlina R (2004). Potensi Buah Kelapa Muda Untuk Kesehatan dan Peng- olahannya. Jurnal Perspektif, 3, 46- 60. \\ Bates GP, Miller VS (2008). Sweat rate and sodium loss during work in the heat. Journal of Occupational Medicine and Toxicology, 3(1): 1-6. https://doi.org- /10.1186/1745-6673-3-4.}

Buwana PA, Wijasena B, Suroto (2016). Pengaruh pemberian air kelapa muda (Cocos nucifera) terhadap kelelahan kerja pada nelayan di Tambak Mulyo Semarang. Jurnal Kesehatan Masyarakat (e-Journal), 4(2356-3346), $350-358$.
Gardiner K, Harrington JM (2005). Occupational Hygiene (Third Edit). Blackwell Publishing.

Jacklitsch B, Williams W, Musolin K, Coca A, Kim JH, Turner N (2016). NIOSH Criteria for A Recommended Standard: Occupational Exposure to Heat and Hot Environments. US Department of Health and Human Services, Publication 2016-106. https://doi.org/Publication 2016-106

Jamaludin J, Lestantyo D, Wahyuni I (2012). Kelelahan Pada Pekerja Bagian Pengepakan di PT. X Semarang. Media Kesehatan Masyarakat Indonesia, 11(1).

Kementerian Ketenagakerjaan Republik Indonesia (2018). Peraturan Menteri Ketenagakerjaan Republik Indonesia Nomor 5 Tahun 2018 Tentang Keselamatan dan Kesehatan Kerja Lingkungan Kerja.

Koradecka D(2010). Handbook of Occupational Safety and Health. United States of America: CRC Press. https://doi.org/10.1201/EBK1439806845

Lerman SE, Eskin E, Flower DJ, George EC, Gerson B, Hartenbau N, et al. (2012). Fatigue risk management in the workplace. Journal of Occupational and Environmental Medicine, 54(2), 231258. https://doi.org/10.1097/JOM.obo13e318247a3bo

Maurits LSK (2017). Selintas tentang kelelahan kerja, Yogyakarta: Amara Books.

Medeiros VFLP, Medeiros AC (2012). Therapeutic Use of Coconut Water O Uso Terapêutico da água de Coco. Journal of Surgical Research, 3(2), 75-83.

Miller V, Bates G (2007). The consequences of environmental heat stress include a reduction in safety due hydration of outdoor workers in North-West Australia. J Occup Health Safety - Aust 
NZ, 23(1), 79-87.

Miller VS, Bates GP (2010). Hydration, hydration, hydration. Annals of Occupational Hygiene, 54(2), 134-136. https://doi.org/10.1093/annhyg/mepo91

Nurmianto E (2004). Ergonomi konsep dasar dan aplikasinya. Surabaya: Penerbit Guna Widya.

Nurullita U, Joko T (2007). Pengaruh beban kerja dan faktor lingkungan fisik terhadap tekanan darah, denyut nadi dan tingkat kelelahan pekerja bagian arc furnace dan rolling mill PT. Inti General Yaja Steel Semarang. Jurnal Kesehatan Lingkungan Indonesia, 6(1), 13-16.

OSHA (2005). OSHA Fact Sheet: Protecting Workers From The Effects of Heat, 2004-2005.

Plog BA, Quinlan PJ(2010). Fundamentals of Industrial Hygiene $5^{\text {th }}$ Edition (Occupational Safety and Health). Braunwald's Heart Disease, 10/e (Fifth Edit). National Safety Council. https://doi.org/10.1016/B978-1-45575134-1.00001-9.

Prades A, Dornier M, Diop N, Pain JP (2012). Coconut Water Uses, Composition and Properties: A Review. Fruits, 67(2), 87-107. https://doi.org/10.1051/fruits/2012002

Reddy EP, Lakshmi TM (2014). Coconut water - properties, uses, nutritional benefits in health and wealth and in health and disease: A Review. Journal of Current Trends in Clinical Medicine \& Laboratory Biochemistry, 2(2), 6-18.

Salami et al.(2015). Kesehatan dan Keselamatan Lingkungan Kerja, Yogya- karta : Gadjah Mada University Press. Sawka (2005). Human water needs. Nutrition Reviews, 63(S1), S30-S39. https://doi.org/10.1301/nr.2005.jun.S30.

Sugiyono (2014). Metode penelitian kuantitatif, kualitatif, dan kombinasi (mixed methods), Bandung: Penerbit Alfabeta.

Sumakmur (2014). Higiene Perusahaan dan Kesehatan Kerja (Hiperkes), Edisi 2, Jakarta: Sagung Seto.

Tarwaka, Bakri SHA, Sudiajeng L (2004). Ergonomi Untuk Keselamatan, Kesehatan Kerja dan Produktivitas. Retrieved from http://shadibakri.uniba.ac.id/wp-content/uploads/2016/o3/Buku-Ergonomi.pdf

Tarwaka (2013). Ergonomi Industri, Cetakan Ketiga, Surakarta: Harapan Press.

United States Department of Labor. (2017). OSHA Technical Manual (OTM)| Section III: Chapter 4 - Heat Stress| Occupational Safety and Health Administration. Retrieved from https://www.osha.gov/dts/osta/otm/ otm_iii/otm_iii_4.html

US Department of Health and Human Services. (2010). NIOSH Fast Fact: Protecting Yourself from Heat Stress.

USDA (2016). National Nutrient Database for Standard Reference Release 28. Nuts, coconut water (liquid from coconuts), 18-19. Retrieved from http://ndb.nal.usda.gov/ndb/foods/show/ 3665 ? fgcd $=\& m a n u=\& l f a c e t=\&$ format $=\&$ count $=\& \max =35 \&$ offset $=\&$ sort $=\&$ qlookup $=$ coconut.

Vita D (2016). Kelapa muda pelepas dahaga sejuta khasiat. Surabaya: Penerbit Stomata. 